p 15-22. In: Hare, M.D.; Brock, J.L., editors. Producing Herbage Seeds.

Grassland Research and Practice Series No. 2,

New Zealand Grassland Association, Palmerston North.

\title{
GRASS SEED PRODUCTION: WEEDS, HERBICIDES AND FERTILISERS
}

\author{
M.P. Rolston ${ }^{1}$, \\ K.R. Brown', \\ M.D. Hare', \\ K.A. Young ${ }^{3}$ \\ 'Grasslands Division, DSIR, Palmerston North \\ *Grasslands Division, DSIR, Lincoln \\ 'Seed Testing Station, MAF, Palmerston North
}

\begin{abstract}
Four weed species (Bromus mollis, Vulpia sp., Poa annua, Stellaria media) occur in $30 \%$ or more of all perennial ryegrass seed samples. Of the listed undesirable species, Avena fatua (wild oat) and Hordeum murinum occurred respectively in 5.3 and $3.5 \%$ of ryegrass seedlots. Only 6 herbicides are registered for use in grass seed crops in New Zealand, 2 for wild oat, and 4 for broadleaved weeds. The results of research on weed control in seedling and established seed crops (ryegrass, cocksfoot, tall fescue, phalaris, prairie grass) are presented.

Fertilisers for grass seed crops discussed are nitrogen $(\mathrm{N})$, phosphorus (P), potassium (K), lime and zinc. Autumn $\mathrm{N}$ is commonly used and will increase seed yields in early flowering species (Festuca rubra, F, arundinacea), but in ryegrass variable results have occurred. Spring $\mathrm{N}$ should be applied at stem elongation. No responses to $\mathrm{P}$ have been reported for ryegrass, while in established cocksfoot responses to $\mathrm{P}$ and $\mathrm{K}$ have been reported. Overliming can induce $\mathrm{Zn}$ deficiencies, and of the grass species only prairie grass may require lime.

Keywords: Lolium, ryegrass, seed production, weed occurrence, Bromus mollis, herbicides, fertilisers, nitrogen, phosphorus, potassium, lime, zinc.
\end{abstract}

\section{HERBICIDES AND WEED CONTROL}

\section{Weeds in Ryegrass Seedcrops}

Weeds reduce yield and profits and also lower the quality of the seedlot for subsequent sowing. Yield losses result from weed competition in the growing crop and from separation losses at harvest and in seed 'cleaning. Economic losses result from the cost of weed control, increased seed cleaning charges and loss in value of seedlots that fail to meet weed contamination standards set by the certification scheme or, for export lots, the regulations of overseas countries.
One of the major quality factors of a seedlot is its analytical purity (Scott and Hampton, 1985) and the New Zealand certification scheme recognises this by specifying the maximum weed seed content allowed in certified seed. This is commonly $0.5 \%$ on a weight basis but ranges from 0.2 to $1.0 \%$ depending on certification class and crop species. Any seedlot found to contain wild oat, nodding thistle or yellow gromwell (effective from 1.1.85) will be rejected from certification (Anon., 1984).

TABLE 1 Occurrence of weed species in perennial ryegrass seedlots* analysed at the Official Seed Testing Station, 1984

\begin{tabular}{|c|c|c|}
\hline Botanical name & Common name & $\begin{array}{l}\text { irence } \\
\%\end{array}$ \\
\hline \multirow{2}{*}{$\begin{array}{l}\text { Bromus mollis (B. hordeaceus) } \\
\text { Vulpia spp. }\end{array}$} & soft brome & 76 \\
\hline & vulpia hair grass & 40. \\
\hline Poa annua & annual poa & 39. \\
\hline Stellaria media & chickweed & 35.1 \\
\hline Sherardia arvensis & field madder & 29.1 \\
\hline Cerastium spp. & mouse-eared chickweed & 27. \\
\hline Capsella bursa-pastoris & shepherd's purse & 16 \\
\hline Trifolium striatum & striated clover & 14. \\
\hline Clyceria spp. & sweet grass & 13. \\
\hline Trifolium glomeratum & clustered clover & 12 \\
\hline Viola arvensis & field pansy & 11 \\
\hline Anthoxanthum & sweet vernal & 10.7 \\
\hline Rumex acetosella & sheep's sorrel & 10 \\
\hline Rumex spp. & docks & 5 \\
\hline Sisymbrium officinale & hedge mustard & 5 . \\
\hline Leontodon taraxacoides & hawkbit & 4.8 \\
\hline Plantago lanceolata & narrow leaved plantain & \\
\hline $\begin{array}{l}\text { Phalaris minor } \\
\text { Polygonum aviculare }\end{array}$ & $\begin{array}{l}\text { lesser canary grass } \\
\text { wireweed }\end{array}$ & $\begin{array}{l}3 . \\
3 .\end{array}$ \\
\hline Lapsana communis & nipplewort & 3. \\
\hline 6 other species** & & 4.2 \\
\hline
\end{tabular}

* Data from original tests in 1445 officially sampled seedlots of Grasslands Nui, Grasslands Ruanui, Ellett, NZ permanent pasture class and uncertified perennial ryegrass.

**Other species in descending order of occurrence, Sonchus asper, Chenopodium album, Arrhenatherum spp., Erodium spp., Polygonum persicaria, Ranunculus repens. 
Twenty six of the most common weed seeds in seedlots of New Zealand-grown perennial ryegrass are listed in Table 1 . It indicates the percentage of samples in which each weed species was recorded during purity analysis (Young et al., 1984) at the Official Seed Testing Station. All are species that are common and widespread in the field (Healy, 1969) although they are not generally regarded as serious weeds. However, because of their ubiquity, they form a major portion of the contaminating weed seed in field-threshed ryegrass seed. This seed is then machine cleaned to achieve the very low levels of weed seed specified by the certification scheme. A number of these common species, particularly the other grass species, have seeds with physical characteristics similar to that of ryegrass. Removing them without excessive loss of good crop seed is very difficult (Hartley, 1969).

Table 2 shows the comparative importance of the various reasons causing downgrading or rejection from certification of ryegrass seedlots. Over $37 \%$ of all changes in certification status at laboratory examination were due to the weed seed fraction exceeding the prescribed level. In all cases one of the species listed in Table 1 was involved, but soft brome was predominant accounting for twothirds of all changes in this category. Fourteen different species were involved in the 34 instances recorded as other species, but two grass species, vulpia hair grass and floating sweet grass, accounted for $50 \%$ of those records.

These weedy grasses are common in the weed seed fraction because they are common occurrence in ryegrass seedcrops and because their seeds are susceptible to damage during harvesting and handling. If the awns of soft brome or vulpia hair grass are broken off their seed dimensions fall into the same range as those of ryegrass and complete separation during machine cleaning cannot be achieved.

Some of the species in Table 1 are not adequately controlled by the presently registered herbicides. Two species, field pansy and nipplewort now contaminate 11 and 3\% respectively of all ryegrass seedlots. Both these species tolerate most hormone herbicides and will be difficult weeds for seed growers to control in the coming years.

Several of these commonly occurring weed seeds can cause problems in exporting to some markets e.g. Rumex spp. (docks) are subject to restrictions on the maximum number per kilogram for entry into the EEC or Canada; Pfantago spp. are subject to restrictions for Canada and some states in the USA.

Table 3 reports the occurrence in perennial ryegrass seedlots of 14 weed species designated by the N.Z. Agricultural Merchants Federation and the Seed Testing Station as undesirable contaminants of seed (Scott, 1980; Young, 1984). Many of these species are included in the lists of prohibited or restricted weeds in the seed quarantine regulations of most countries and thus, seedlots containing them cannot be exported. Dodder, hemlock, nassella tussock, nodding thistle, ragwort and wild oat seed are gazetted noxious plants throughout New Zealand. Generally the number of seedlots contaminated with these species is very small, although barley grass and wild oat occur at levels giving cause for concern in annual and hybrid ryegrass cultivars.

TABLE 2 Reasons for downgrading and rejection from certification of ryegrass seedlots at laboratory examination, Official Seed Testing Station, 1984.

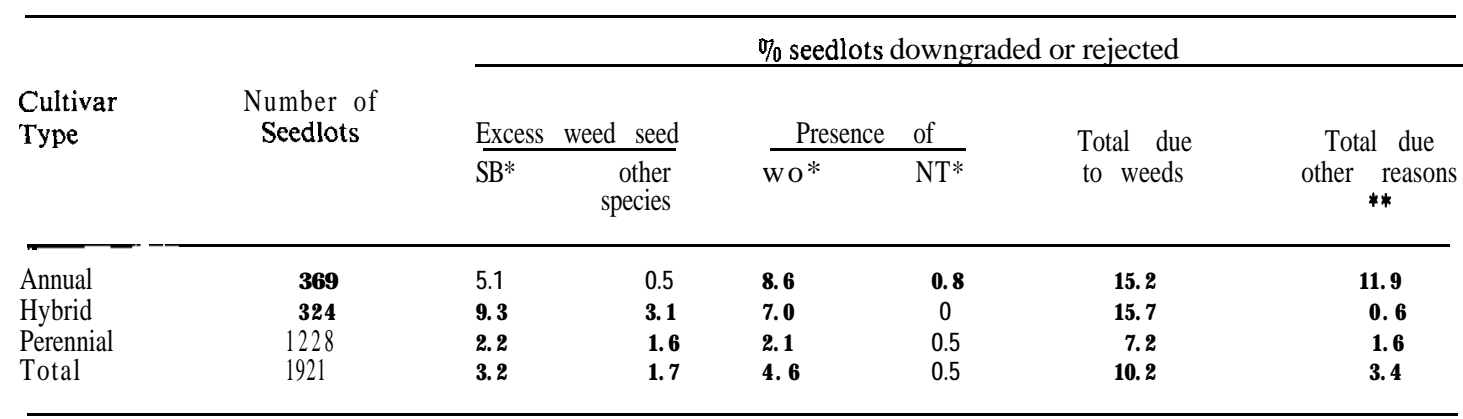

* $\mathrm{SB}=$ soft brome, $\mathrm{WO}=$ wild oat, $\mathrm{NT}=$ nodding thistle.

**Downgraded or rejected because seedlot failed to meet pure seed standard (because of inert matter) or seed weight standard of $4 \mathrm{~g} / 1000$ seeds for Grasslands Moata annual ryegrass. 
TABLE 3 Percent occurence of specified undesirable weeds in officially sampled certified and uncertified ryegrass seed lots analysed at the Official Seed Testing Station during 1984.

\begin{tabular}{|c|c|c|c|c|}
\hline Number of samples $\dagger$ & $\begin{array}{c}\text { All samples } \\
2727\end{array}$ & $\begin{array}{c}\text { Perennial } \\
1646\end{array}$ & $\begin{array}{c}\text { Hybrid } \\
378\end{array}$ & $\begin{array}{c}\text { Annual } \\
703\end{array}$ \\
\hline $\begin{array}{l}\text { Wild oat Avena fatua* } \\
\text { barley grass Hordeum murinum } \\
\text { winged thistle Carduus tenuiflorus } \\
\text { nodding thistle Carduus nutans* } \\
\text { Scotch thistle Cirsium vulgare } \\
\text { Californian thistle Cirsium arvense } \\
\text { yellow gromwell Amsinckia calcycina } \\
7 \text { other species** }\end{array}$ & $\begin{array}{l}5.3 \\
3.5 \\
2.8 \\
1.3 \\
1.0 \\
0.9 \\
0.5 \\
0.3\end{array}$ & $\begin{array}{l}2.2 \\
2.3 \\
3.0 \\
1.2 \\
0.9 \\
0.4 \\
0.6 \\
0.2\end{array}$ & $\begin{array}{l}6.9 \\
3.4 \\
1.1 \\
0.5 \\
1.1 \\
1.0 \\
0.5 \\
0\end{array}$ & $\begin{array}{r}11.8 \\
7.8 \\
2.4 \\
2.4 \\
1.1 \\
1.4 \\
0.4 \\
0.6\end{array}$ \\
\hline
\end{tabular}

* Records for these species relate to uncertified seedlots,

**Cardaria draba, Leucanthemum vulgare, Conium maculatum, Convolvulus arvensis, Cuscuta spp., Stipa trichotoma, Senecio jacobaea.

$\uparrow$ Original tests only.

Included in Table 3 are the three species, wild oat, nodding thistle and yellow gromwell, whose presence in seedlots results in rejection from certification. Wild oat is the greatest single cause of change in certification status of ryegrass seedlots (Table 2). Small wild oat seeds that have had their awns and hair removed during harvesting and handling are difficult to separate from ryegrass seedlots. Nodding thistle occurrence declined from $2.42 \%$ in 1976 to $0.36 \%$ in all ryegrasses tested for certification (Young, 1984) and is of relatively minor cause for rejection of ryegrass seed lots. The regulation against yellow gromwell was only introduced this year. Yellow gromwell has been recorded most frequently in ryegrass seedlots from mid Canterbury (Young, 1985).

The importance of weed control to seed growers is emphasised by the fact that one in 10 of all ryegrass seedlots submitted for laboratory examination as part of the certification scheme are downgraded or rejected because of failure to meet weed standards. The figure rises to one in 6 if just annual and hybrid cultivars are considered (Table 2). These downgradings and rejections occur after all the expenses of producing and cleaning the seed have been incurred and can severely influence the sale of, and financial returns on these seedlots. Almost all the ryegrass seedlots rejected last year because of wild oat had a pure seed fraction of 99\% or greater, yet under the Noxious Plant Act 1978 they cannot legally be sold or distributed for sowing whilst containing a gazetted noxious weed.

The results presented here indicate that weedy grass species, particularly wild oat and soft brome, are the major problem weeds in certified ryegrass seed production. Effective field control of these species is essential because if their seed is damaged during harvesting, machine cleaning is unable to effectively remove all seed contaminating ryegrass seedlots.

Just 6 herbicides are registered for use in grass seed crops (Table 4). In practice farmers use a wide range of herbicides including many that have registrations for either pastures or TABLE 4 Herbicides registered for grass seed crops (from Butler and Bourdot, 1983).

\begin{tabular}{llcl}
\hline Common name & $\begin{array}{l}\text { Product } \\
\text { name }\end{array}$ & $\begin{array}{c}\text { Product } \\
\text { rate } \\
\text { (litres/ha) }\end{array}$ & Comment \\
\hline MCPB & various & $2.5-3.5$ & Seedling broad leaf control \\
$2,4-D B$ & various & $2.5-3.5$ & Seedling broad leaf control \\
MCPA & various & $2-3$ & Seedling broad leaf control \\
bentazone & Basagran & Mayweeds, chamomiles, storksbill \\
flamprop-methyl & Sniper & 5 & Wild oat control in ryegrass \\
difenzoquat* & Avenge 200A & 5 & Wild oat control in ryegrass \\
\hline
\end{tabular}

*Experimental use permit, limited sale. 
cereals. However, there are pitfalls in assuming that pasture or cereal herbicides or even ryegrass seed crop herbicides can be used on all species of grass seed crops, Some herbicides that are effective for weed control in grass seed crops are outlined below, based on research at Grasslands Division, Palmerston North by Rolston (unpub. data). Herbicides that are not registered are used at the grower's risk.

\section{Seedbed preparation}

Perennial weeds including couch (Agropyron repens), Californian thistle and yarrow (Achillea millefolium), are controlled best with glyphosate before seedbed preparation begins. Other weed species can be controlled using the stale seedbed technique. Seedbed preparation is completed at least 10 to 15 days before sowing, and emerging weeds are sprayed with paraquat before or immediately after sowing.

\section{Grass weed control in seedling stands}

Flamprop-methyl (Sniper) and difenzoquat (Avenge) can be used in ryegrass for wild oat control. Flamprop-methyl greatly suppresses vegetative growth in cocksfoot and phalaris and moderately in prairie grass. Ethofumesate (Norton) is also active on wild oat and a number of other grass species and can be used in ryegrass, fescue and cocksfoot that are not undersown with legumes.

Poa annua can be serious after autumn sowings especially of slow-establishing grasses such as cocksfoot. Ethofumesate at $1.5 \mathrm{~kg} / \mathrm{ha}$ controlled annual poa and increased seed yields of autumn sown Wana cocksfoot 7 fold (Brown et al., 1983).

Ryegrass can be a serious weed in both tall fescue and cocksfoot seed crops. Despite numerous experiments we have not been successful at controlling ryegrass in seedling crops of these two species.

Of the 7 common contaminant grasses in ryegrass (Table 1), 6 species, soft brome, vulpia hair grass, annual poa, floating sweet grass, wild oat and barley grass are susceptible to moderately susceptible to ethofumesate at 1.5 to $2.0 \mathrm{~kg}$ ai $/$ ha. However, at a cost of $\$ 100$ per $\mathrm{kg}$ ai, this treatment would be economic only for high value ryegrass seedlots. Both soft brome and vulpia hair grass (Table 1) are moderately susceptible to TCA but the tolerance of ryegrass seed crops to this product is unknown.

Volunteer cereals, especially from sprout resistant cultivars in ryegrass are controlled in the UK with a TCA+ethofumesate (Nortron) mixture $(5.0+0.8 \mathrm{~kg}$ ai $/ \mathrm{ha})$ (Johnson et al., 1982). Further research is required on this mixture in New Zealand for economic control of a range of grass weed species. Several grass weeds are regionally important, e.g. lesser canary grass in the Manawatu, and difficult to control.

Some grass cultivars show tolerances to several herbicides so that other grasses can be controlled, e.g. chewings fescue is tolerant of sethoxydim (Alloxal-S) at $1.0 \mathrm{~kg}$ ai/ha; prairie grass is tolerant of chlorsulfuron (Glean) at $20 \mathrm{~g}$ ai/ha, and methabenzthiazuron (Tribunil) at $1.5 \mathrm{~kg}$ ai/ha.

\section{Broad leaved weeds}

Nodding thistle and yellow gromwell are not controlled with MCPA. However, MCPA mixed with dicamba for nodding thistle or with bromoxynil for yellow gromwell gives adequate control. Follow up spot spraying or roguing should be carried out. Where difficult-tocontrol weeds occur, e.g. field pansy, or nipplewort no clover should be sown with the grass seed to give a greater flexibility in the choice of herbicide for control. Herbicide mixes containing bromoxynil and ioxynil are being used to control these species.

Bentazone (Basagran) is both registered and useful alone or in mixtures with hormones, e.g. MCPB to control a wide range of species including chamomiles, stinking mayweed, cleavers and storksbill. Dinoseb is also active on many weeds that are at an early growth stage.

While many cereal herbicides are used in grass seed crops, some exceptions that cause serious crop damage to many species are chlorsulfuron (Glean) and diclofop-methyl (Hoegrass), and dicamba on browntop seed crops.

\section{Established crops}

Most cultivars once established for 12 months will tolerate a range of soil active herbicides that will control many annual or shallow rooted weeds. These herbicides include atrazine, simazine and diuron at 1.0 to $2.5 \mathrm{~kg}$ ai/ha. Prairie grass is an exception, being readily damaged by these herbicides. Ryegrass 
is more sensitive than cocksfoot, phalaris or tall fescue and lower rates should be used. Ryegrass as a weed in cocksfoot can be controlled with a diclofop-methyl (Hoegrass) + atrazine mixture $(1.0+1.0 \mathrm{~kg} \mathrm{ai} / \mathrm{ha})$, while terbicil (Sinbar) at $0.5 \mathrm{~kg}$ ai $/$ ha plus diuron gives excellent weed control in cocksfoot seed crops.

\section{Precautions and failures}

The use of herbicides is not without its problems. Hormone based herbicides can drift and damage adjacent sensitive crops. Clovers are commonly sown as a companion species with ryegrass and herbicides may damage the clovers.

The growth stages at which grass seed crops are sensitive to hormone sprays are similar to those in cereals. In general do not apply MCPA, 2,4-D or other hormone based herbicide mixtures before the 3 to 4 leaf stage or after stem elongation has begun.

Environmental conditions at the time of herbicide application are important. Rain within 4 to 6 hours can reduce herbicide effectiveness; difenzoquat efficacy is rain sensitive for up to 24 hours after application. Cold, moist conditions enhance ethofumesate activity while warm conditions enhance bentazone and dinoseb.

Soil residual herbicides (e.g. simazine, diuron) should be applied in late autumn or winter when crop growth is slow, soils are moist and rain is expected so that the herbicide is washed off the leaf. To minimise leaf absorption by the crop reduce the leaf area by grazing before spraying. On light soils (low clay content) and low organic matter soil rates of herbicide should be lower.

The challenge of herbicide weed control is to understand the complex interaction between plant, soil, climate and chemical and to be able to use enough herbicide to kill the weeds, without over dosing and damaging the crop. Herbicide rotations-and crop rotations must be carefully planned to avoid a build-up of difficult to control weed species.

\section{FERTILISERS}

\section{Site Description}

Much of the considerable research on the fertiliser requirements of grass seed crops is difficult to interpret because of inadequate site descriptions. A site description should include soil type, rainfall, cropping history, soil total nitrogen and carbon \%, and MAF Quicktest analyses (exchangeable $\mathrm{K}$, Olsen $\mathrm{P}$ and $\mathrm{pH}$ ), for any site where fertiliser trials are being conducted (R. Ball, pers. comm). Remember that sampling should be to $15 \mathrm{~cm}$ depth on arable soils. In addition, measurement of soil mineral $\mathrm{N}$ to $60 \mathrm{~cm}$ depth could be helpful.

\section{Nitrogen}

If all other elements are not limiting, nitrogen $(\mathrm{N})$ is the main nutritional determinant of seed yield in grasses. Nitrogen fertilisers are now widely used in grass seed production. The main questions on $\mathrm{N}$ use are time of application (autumn $\mathrm{N}$ and split spring $\mathrm{N}$ ), amount and type of $\mathrm{N}$ and plant species effects.

\section{Autumn Nitrogen}

The use of autumn $\mathrm{N}$ at sowing is a common practice. Research results with perennial ryegrass (Lolium perenne) are shown in Table 5. The response in Hill's trials (1972) was associated with a $38 \%$ increase in seed heads. Autumn $\mathrm{N}$ fertiliser can enhance vegetative tillering and therefore increase seed head numbers, but other factors are also important. Soil residual N, time of sowing (and related to this, soil temperatures), sowing rate and soil moisture in autumn all influence the density of vegetative tillers in early spring.

TABLE 5 Effects of autumn and autumn + spring $\mathrm{N}$ on perennial ryegrass seed yields.

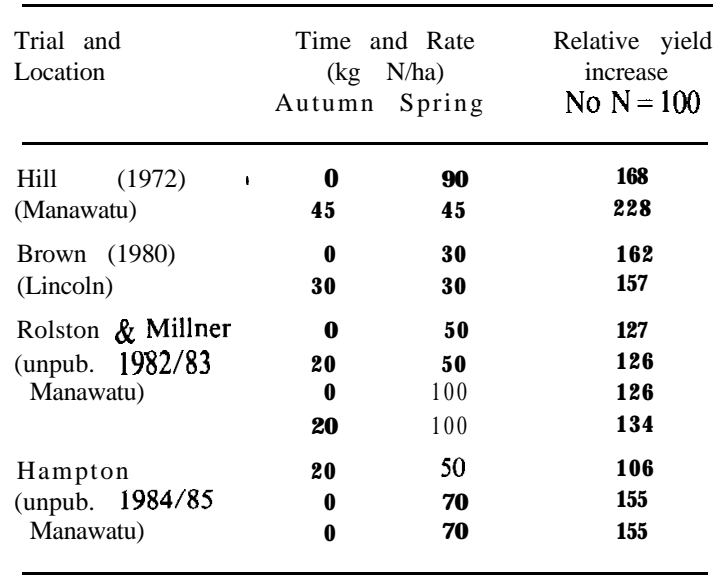

The response to autumn $\mathrm{N}$ appears to be site specific. Unless, a site is truly $\mathrm{N}$ deficient (depends on previous cropping history) no response to autumn $\mathrm{N}$ can be expected in perennial ryegrass. 
The use of autumn $\mathrm{N}$ on established stands depends on species. In general seed yields are increased when early-flowering species, e.g. chewings fescue (Festuca rubra), tall fescue (F. arundinaceae) and cocksfoot (Dactylis glomerata), receive autumn N (Hill and Blackstock, 1983; 'Nordestgarrd, 1980). Spring $N$

Researchers generally agree with the concept that $\mathrm{N}$ fertiliser and management used in grass seed production should be related to the morphological and physiological state of the crop (Cooper and Saeed 1949; Langer 1956; Hill 1972). The translation of this concept into practice results in a conflict of views. Early spring $\mathrm{N}$ should increase spring tiller numbers (Langer, 1980), mid spring $\mathrm{N}$ at floret initiation (stem elongation) will increase floret density by increasing the number of florets/head (Brown, 1981), while late spring $\mathrm{N}$ can increase seed weight (Griffiths et al., 1973).

In perennial ryegrass tillers formed in early spring can be fertile (Field-Dodgson, 1971) and in this trial increasing the rate of early $\mathrm{N}$ (applied September 1) increased head density and seed yield. This response is presented as being linear, but it can also be interpreted as curve-linear with no yield responsk above a seed head density of $3400 / \mathrm{m}^{2}$ (170 ears per $30 \mathrm{~cm}$ row; in Figure 1, Langer, 1980). If reproductive tiller numbers (head density) in the range of $2000-4000 / \mathrm{m}^{2}$ are not limiting seed yield (Hebblethwaite and Ivins, 1978), there will be no response from early $\mathrm{N}^{\prime}$ and split $\mathrm{N}$ application. Then seed yield will depend primarily on conditions governing the number of seeds set per spikelet (Hampton and Hebblethwaite, 1983). The results of Brown (1980) support this view, and for perennial ryegrass one application of $\mathrm{N}$ at stem elongation (floret initiation) will be adequate if fertile tiller numbers are not limiting.

\section{Species responses}

Overseas trials show that early-flowering species respond to autumn $\mathrm{N}$, e.g. chewings fescue (Nordestgaard, 1980), tall fescue (Griffiths et al., 1973; Youngberg and Wheaton, 1979; Hill and Blackstock, 1983) and cocksfoot (Nordestgaard, 1980; 1983). New Zealand results on cocksfoot are conflicting, with Lambert (1956) reporting a response from autumn N, while Harris et al. (1973) found no response.

The timing of spring $\mathrm{N}$ for late-flowering species (timothy, browntop) should be delayed until stem elongation; e.g. Brown (1985) reports that Sefton and Egmont browntop responded to late October/November $\mathrm{N}$, but not to earlier applications.

Stem elongation in most perennial and hybrid ryegrasses begins in late September, and in annual ryegrass in early October. $\mathrm{N}$ fertiliser should be applied at, or immediately before, stem elongation (Brown, 1980). Late-flowering ryegrass can flower 2 to 6 weeks later, and spring $\mathrm{N}$ should be delayed until stem elongation is observed.

\section{Amount of $N$}

For ryegrass, Brown (1980) reported a seed yield of $390 \mathrm{~kg}$ seed/ha response from low rates of spring $\mathrm{N}(28 \mathrm{~kg} / \mathrm{ha})$. In many New Zealand trials $40-50 \mathrm{~kg} \mathrm{~N} / \mathrm{ha}$ applied in spring has increased seed yields by about $220 \mathrm{~kg} / \mathrm{ha}$ (Ball and Field 1982).

The amount of $\mathrm{N}$ taken up in seed + straw ranges from 50 to $80 \mathrm{~kg} \mathrm{~N} /$ ha (Table 6) for crops with straw yields of 5,000 to 10,000 $\mathrm{kg} / \mathrm{h}$. Hampton et al. (1983) reviewed European trials and found the optimum levels of application cited for perennial ryegrass seed crops range from 60 to $135 \mathrm{~kg} \mathrm{~N} / \mathrm{ha}$, the exact level depending on the $\mathrm{N}$ status of the soil. Nitrogen application in excess of $120 \mathrm{~kg} / \mathrm{ha}$ (equivalent to $280 \mathrm{~kg}$ urea/ha) does not usually increase seed yield significantly over that of recommended rates, because of increased seed abortion as a consequence of competition for assimilate supply by secondary vegetative tillers.

TABLE 6 Nutrient losses $(\mathrm{kg} / \mathrm{ha})$ in seed and straw (adapted from Davis, 1939)

\begin{tabular}{|c|c|c|c|c|}
\hline Ryegrass & $\mathrm{N}$ & $\mathrm{P}$ & $\mathrm{K}$ & $\mathrm{Ca}$ \\
\hline Seed $(1000 \mathrm{~kg} / \mathrm{ha}) \quad 1$ & 19 & 4 & 8 & 2 \\
\hline Straw $(5500 \mathrm{~kg} / \mathrm{ha}) 3$ & & 7 & 80 & 17 \\
\hline Total 5 & 52 & 11 & 88 & 19 \\
\hline \multicolumn{5}{|l|}{ Cocksfoot } \\
\hline Seed $(500 \mathrm{~kg} / \mathrm{ha})$ & 13 & 2 & 5 & 1 \\
\hline Straw $(5500 \mathrm{~kg} / \mathrm{ha}) 3$ & 30 & 6 & 81 & 17 \\
\hline Total & 43 & 8 & 86 & 18 \\
\hline
\end{tabular}

For cocksfoot in the South Island applications of 80 to $100 \mathrm{~kg} \mathrm{~N} / \mathrm{ha}$ either in early spring or split between spring and autumn approximately doubled the yield of dressed seed (Sears, 1950; Harris et al., 1973).

Assuming that a grass seed crop requires about $130 \mathrm{~kg} \mathrm{~N} /$ ha (Hampton et al., 1983), can we determine the $\mathrm{N}$ status of the soil and 
therefore predict fertiliser $\mathrm{N}$ requirements?

Four methods for predicting the $\mathrm{N}$ requirements of wheat (Greenwood et al., 1984) are:

1 previous cropping history

2 'deep nitrate' soil test

3 winter rainfall method

4 soil incubation method

The last test is now available to growers. Although these tests have not been developed for grass seed, they can (in the absence of no other information) be used as guides for grass seed crops. As a general rule, $\mathrm{N}$ fertiliser recommendations for crops are still based largely on local farming experience and practice (Goh, 1983).

\section{Nitrogen form}

The common forms of $\mathrm{N}$ used on seed crops (Table 7) range in cost from 102 to 263 $\mathrm{c} / \mathrm{kg}$ N. Cost should be the main determining factor for choice of nitrogen fertiliser. $\mathrm{N}$ losses through volatilisation (Theobald and Ball, 1984) are not a problem with spring applications, but may influence the choice in autumn, when urea should be avoided on dry soils when temperatures are warm.

TABLE 7 Forms and costs of $\mathrm{N}$ fertiliser commonly used in seed production.

\begin{tabular}{lcc}
\hline & \%oN & $\begin{array}{c}\text { cost } \\
\mathrm{Q} / \mathrm{kg}\end{array}$ \\
& & $\mathrm{N}$ \\
\hline Urea & & 102 \\
Ammonium sulphate & 46 & 132 \\
Calcium ammonium nitrate & 21 & 166 \\
Diammonium phosphate (DAP) & 18 & 263
\end{tabular}

Forms of $\mathrm{N}$ that combine $\mathrm{S}$ or $\mathrm{P}$ are useful for correcting nutrient deficiencies. $\mathrm{P}$ is rarely deficient for grass seed crops, while forms that combine $\mathrm{Ca}$ are useful for counteracting soil acidity effects of $\mathrm{N}$ fertiliser, although lime would usually be cheaper. The importance of $S$ in ammonium sulphate (AS) in correcting $S$ deficiencies is unknown. This fertiliser is widely used on cropping soils in Canterbury, an area known to be $\mathrm{S}$ deficient and historically farmers have preferred AS to other $\mathrm{N}$ fertilisers ( $\mathrm{R}$. Ball, pers. comm.). Farmer reports of better responses to AS compared to other $\mathrm{N}$ fertilisers may reflect on additional response to the $\mathrm{S}$ component of AS.

Major elements (P, K, Mg, S)

In New Zealand few responses to $\mathrm{P}, \mathrm{K}, \mathrm{Mg}$ or S have been reported for grass seed crops.

N-P-K-S fertilisers are commonly used at establishment although there are few results to support this practice. Brown (1977, 1980) reported no response to $\mathrm{P}$ and $\mathrm{K}$ in Tama $(L$. multiflorum) or Nui perennial ryegrass, even on sites considered to be $\mathrm{P}$ deficient for pasture production. In earlier trials Sears $(1947,1950)$ reported no $\mathrm{P}$ response in ryegiass or cocksfoot, but Harris et al. (1973) reported responses in cocksfoot from spring $\mathrm{P}$ and autumn K.

Nutrients are lost during seed production (Table 6) particularly in straw. Deficiencies if they occur are more likely to be of $\mathrm{K}$, especially in stands that are harvested for more than one year.

We suggest that unless soil tests show extreme deficiencies, there will be no benefit from using $\mathrm{P}, \mathrm{K}$ fertiliser at establishment, but in second year crops $\mathrm{K}$ especially should be replaced.

The role of sulphur $(S)$ in grass seed production is not known, and further research is required.

As a fertiliser $50 \%$ potash serpentine (P:K:S:Ca:Mg = 4:25:4:8:3:) more closely matches nutrients lost in grass seed production than other fertilisers.

To replace the nutrient lost in seed and straw removal for second year and subsequent crops, a crude mass balance approach can be adopted by adding back, with fertiliser, amounts equivalent to those removed in Table 6 .

\section{Lime}

Grass seed yield responses to lime are unlikely on sites of $\mathrm{pH} 5.0$ and above, with the possible exception of prairie grass. At Palmerston North poor establishment of prairie grass wass associated with a soil $\mathrm{pH}$ of 4.5 to 4.8 and until further evidence is available, we suggest liming to a soil $\mathrm{pH}$ of 5.5 for prairie grass.

\section{Trace elements}

In New Zealand trace element deficiencies affecting grass seed production have rarely been reported. Overliming beyond pH 6.4 may trigger the occasional micronutrient deficiency, e.g. manganese in wheat (McLeod, 1961) and zinc in pasture (McLeod and Quin, 1979), and similar responses may occur in grass seed crops. 
One ryegrass seed grower in the Methven district increased seed yields using zinc on an overlimed field (G. Lill, pers. comm.).

\section{REFERENCES}

Anonymous, 1984. Seed Certification 1984. Agdata series. Ministry of Agriculture and Fisheries, Wellington. 44 PP.

Ball, P.R.; Field, T.R.O. 1982. p 44-64. In: Lynch P.B., editor. Nitrogen Fertilizers in New Zealand Agriculture. New Zealand Institute of Agricultural Science, Wellington.

Brown, K.R. 1977. New Zealand Journal of Experimental Agriculture 5: 143-6.

Brown, K.R. 1980. p 12-14. In: Lancashire, J.A., editor. Herbage Seed Production. Grassland Research and Practice Series No. 1, New Zealand Grassland Association, Palmerston North

Brown, K.R. 1981. Proceedings of the 14th International Grasslands Congress: 266-8.

Brown, K.R.; Rolston, M.P.; Archie W.J. 1983. Proceedings of the $\mathrm{New}$ Zealand Grassland Association 44: $24-9$.

Brown, K.R. 1985. New Zealand Journal of Experimental Agriculture. In press.

Butler, J.H.B.; Bourdot, G.W. 1983. Aglink FPP 397 (2nd revise), Information Services, Ministry of Agriculture and Fisheries, Wellington

Cooper, J.P.; Saeed, S.W. 1949. Journal of Ecology 37: 233-59.

Davis, R.P. 1939. Welsh Journal of Agriculture 5: 250-60.

Field-Dodgson, J.R.C. 1971. The effect of nitrogen on ryegrass seed production. M.Agr. Sci. Thesis, Lincoln College.

Goh, K.M. 1983. Proceedings Agronomy Society of New Zealand 13: 1-14.

Greenwood, P.B.; Quin, B.F.; Sinclair, A.G. 1984. Fertiliser Recommendations for pastures and Crops in New Zealand. 2nd Edition. MAF: 32-3.

Griffiths, D.J.; Roberts, H.M.; Lewis, J. 1973. Report Welsh Plant Breeding Station: 117-23.

Hartley, J.R. 1969. Proceedings 22nd New Zealand Weed and Pest Control Conference 143-148.

Hampton, J.G.; Hebblethwaite, P.D. 1983. Journal of Applied Seed Production I: 23-25.

Hampton, J.G.; Clemence, T.G.A.; Hebblethwaite, P.D. 1983. G rass and Forage Science 38: 97-105.

Harris, A.J.; Brown, K.R.; Turner, J.D.; Johnston, J.M. Ryan, D.L; Hickey, M.J. 1973. New Zealand Journal of Experimental Agriculture I: 139-63.
Healy, A.J. 1969. p 261-333. In: Knox, G.A., editor'The Natural History of Canterbury. A.H. and A.W. Reed, Wellington.

Hebblethwaite, P.D.; Ivins, J.D. 1978. Journal of the British G rasslands Society 33: 159-66.

Hill, M.J. 1972. Proceedings Agronomy Society of $\mathrm{New}$ Zealand 2: 5-10.

Hill, R.D.; Blackstock, J.McK. 1983. Australian Seed Science Newsletter 9: 19-30.

Johnson, J. 1982. Proceedings of the 1982 British Crop Protection Conference- Weeds: 407-413.

Lambert, J.P. 1956. New Zealand Journal of Science and Technology 37: 467-77.

Langer, R.H.M. 1956. Annals of Applied Biology 44: 166-187.

Langer, R.H.M. 1980. p 6-1 1. In: Lancashire, J.A., editor. Herbage Seed Production. Grassland Research and Practice Series No. 1, New Zealand Grassland Association, Palmerston North

McLeod, C.C.S. 1961. New Zealand Journal of Agriculture 103: $\quad \mathbf{5 2 9 - 3} 1$.

McLeod, C.C.S.; Quin, B.F. 1979. New Zealand Journa of Experimental Agriculture 7: 135-9.

Nordestgaard, A. 1980. p 105-19. In: Hebblethwaite, P.D. editor. Seed Production. Butterworths, London.

Nordestgaard, A. 1983. Proceedings 14th International G rasslands Congress. 241-53.

Scott, D.J. 1980. p 103-109. In: Lancashire, J.A., editor. Herbage Seed Production. Grassland Research and Practice Series No. 1, New Zealand Grassland Association, Palmerston North.

Scott, D.J.; Hampton, J.G. 1985. p 43-52. In: Hare, M.D.; Brock, J.L., editors. Producing Herbage Seeds. Grassland Research and Practice Series No. 2, New Zealand Grassland Association, Palmerston North.

Sears, P.D. 1947. New Zealand Journal of Agricultural Research 75: 229-34.

Sears, P.D. 1950. Ibid 80: 379-84.

Theobald, P.W.; Ball, P.R. 1984. Proceedings of the New Zealand G rassland Association 45: 263-8.

Young, K.A. 1984. In: Annual Report Official Seed Testing Station 1983. p 30-31, Ministry of Agriculture and Fisheries, Palmerston North.

Young, K.A. 1985. In: Annual Report Official Seed Testing Station, 1984. p 56-59, Ministry of Agriculture and Fisheries, Palmerston North.

Young, K.A.; Scott, D.J.; Hampton, J.G. 1984. Seed quality determination. AgLink FPP 828, Ministry of Agriculture and Fisheries, Wellington.

Youngberg, H.; Wheaton, H.N. 1979. Agronomy Journal 74: 891-92.

\section{DISCUSSION}

Q. At what $K$ levels would you expect a response from potassic fertiliser?

A. If soil test indicates a $\mathrm{K}$ deficiency then it is advisable to aoply some.

Q. Do seasons make any difference to the amount of $N$ needed to be applied?

A. No. Apply the $\mathrm{N}$ at stem elongation. Also a soil test is vital. In a recent trial soil tests from one site in a field recommended $0 \mathrm{~kg} \mathrm{~N} / \mathrm{ha}$ and another site $60 \mathrm{~kg} \mathrm{~N} / \mathrm{ha}$. These amounts were applied and the seed yields were the same from both sites.
Comment. There was considerable debate on determining the actual amount of $\mathrm{N}$ fertiliser that was needed to be applied to seed crops. With the total $\mathrm{N}$ requirements for the seed crop of around $130 \mathrm{~kg} / \mathrm{ha}$ and the soil $\mathrm{N}$ test indicating the amount available in the soil, the amount needed to be applied is the difference between the two. The soil $\mathrm{N}$ test is supplied as parts per million (ppm) which is approximately equivalent to $\mathrm{kg} \mathrm{N} / \mathrm{ha}$ sampled to $7.5 \mathrm{~cm}$ depth. Rate of $\mathrm{N}$ to be applied $=130$-soil $\mathrm{N}$ test value 


\section{White clover seed production}

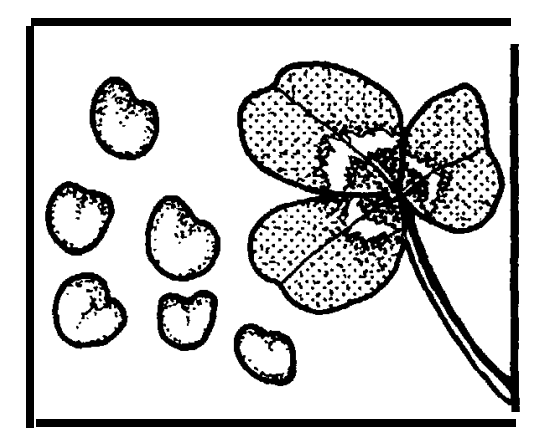

